\title{
HAMBATAN KOMUNIKASI ANTAR BUDAYA MAHASISWA NTT DI YOGYAKARTA
}

\author{
Aleksis Febrian Go, Irene Santika Vidiadari \\ Prodi Ilmu Komunikasi Fakultas Ilmu Sosial dan Politik \\ Universitas Atma Jaya Yogyakarta \\ Jl Babarsari 44 Yogyakarta \\ Email : aleksisfebriango@gmail.com, irene.vidiadari@uajy.ac.id
}

\begin{abstract}
This study discuss the barriers to intercultural communication experienced by students from East Nusa Tenggara (Nusa Tenggara Timur or NTT) while studying in Yogyakarta. This research starts from the condition of Yogyakarta as one of the destination for students from all over Indonesia to continue their educations, especially students from NTT. This research use qualitative descriptive as a method, data collected by interviewing the students from NTT and also collecting data from the media. The results indicate that the differences of language, habits, and perceptions made the barriers to intercultural communication for NTT students. In addition, the stereotypes attached to NTT students such as troublemaker, came from underdeveloped area, and easily commit to criminal acts are the sources of gaps between NTT students and other people around them
\end{abstract}

Keywords: barriers to intercultural communication, conflicts, NTT students, stereotypes.

\begin{abstract}
Abstrak
Penelitian ini membahas mengenai hambatan komunikasi antar budaya yang dialami oleh mahasiswa yang berasal dari Nusa Tenggara Timur (NTT) selama menempuh pendidikan di kota Yogyakarta. Penelitian ini bermula dari kondisi Yogyakarta yang menjadi salah satu tujuan mahasiswa dari seluruh Indonesia untuk melanjutkan pendidikan tinggi. Salah satunya mahasiswa dari NTT. Penelitian ini merupakan studi deskriptif kualitatif, pengumpulan data dilakukan dengan wawancara dan mengumpulkan data dari media. Hasil penelitian ini menunjukkan bahwa perbedaan bahasa, kebiasaan, dan persepsi menjadi hambatan bagi mahasiswa NTT untuk berkomunikasi di Yogyakarta. Selain itu, adanya stereotipe yang dilekatkan kepada mahasiswa NTT seperti terbelakang, suka membuat keributan, dan rentan melakukan tindakan kriminal menjadi sumber adanya kesenjangan antara mahasiswa NTT dan mahasiswa yang berasal dari daerah lain.
\end{abstract}

Kata kunci : Hambatan komunikasi, konflik, mahasiswa NTT, stereotipe. 


\section{PENDAHULUAN}

Komunikasi merupakan hal yang penting pada proses kehidupan seorang manusia. Komunikasi yang berjalan dengan baik akan menentukan interaksi yang terjadi diantara tiap individu berjalan dengan baik pula. Interaksi tersebut bisa berupa interaksi secara perorangan, kelompok ataupun organisasi. Komunikasi yang lancar menyebabkan semua hal ini dapat berjalan secara optimal. Sejak manusia tersebut lahir ke dunia,manusia tersebut telah melakukan tindakan komunikasi. Proses komunikasi berlangsung secara terus menerus selama manusia tersebut hidup di dunia. Bisa dikatakan bahwa komunikasi merupakan bagian terpenting bagi kehidupan manusia. Komunikasi terjadi di mana saja. Interaksi komunikasi biasanya menyangkut hubungan yang terjadi diantara tiap pribadi anggotanya. Interaksi dapat terlihat nyata jika adanya hubungan timbal balik yang melibatkan kepentingan individu dan juga kepentingan kelompok. Suatu proses interkasi terjadi di sebuah lingkungan sosial. Dalam proses interaksi tersebut seorang individu dituntut untuk memiliki kemampuan berkomunikasi dengan manusia lainnya, meskipun terkadang dalam suatu proses interaksi di tengah masyarakat memiliki perbedaan budaya.
Perbedaan tersebut meliputi bahasa dan adat istiadat. Oleh karena itu manusia perlu sekali mempelajari komunikasi antarbudaya, sehingga dapat memperlancar interaksi dengan individu atau kelompok yang memiliki latar belakang budaya,adat istiadat serta bahasa yang berbeda.

Yogyakarta, sebagai kota pelajar, menjadi kota yang dihuni oleh mahasiswa dari berbagai tempat di Indonesia. Jawapos (2018) pada salah satu beritanya menuliskan bahwa mahasiswa yang menempuh studi di Yogyakarta pada tahun 2018 berjumlah sekitar 350.000 mahasiswa. Jumlah ini terus bertambah seiring dengan pertumbuhan program studi baru yang tersebar di berbagai universitas negeri dan swasta di Yogyakarta. Keberagaman daerah asal dari mahasiswa di Yogyakarta menyebabkan secara tidak langsung menjadikan kota ini sebagai daerah yang plural. Salah satu propinsi penyumbang mahasiswa yang menyemarakkan keberagaman di Yogyakarta adalah propinsi Nusa Tenggara Timur (NTT). Setidaknya, pada tahun 2013 terdapat sebanyak 14.000 orang warga NTT yang sekolah hingga bekerja di Yogyakarta (Viva, 2013).

Persoalan lain yang muncul jika melihat persoalan mahasiswa NTT di 
Yogyakarta adalah kejadian konflik yang pernah terjadi di kota ini. Kejadian yang cukup menyita perhatian adalah kasus penembakan di Lapas Cebongan (Pos Kupang, 2013). Kasus ini membawa dampak bagi mahasiswa NTT yang sedang melanjutkan studi di Yogyakarta. Sejak peristiwa itu terjadi banyak ancaman dan isu yang beredar setelah peristiwa itu. Peristiwa ini kemudian menyebabkan Asrama Mahasiswa NTT di Yogyakarta di kosongkan (Merdeka, 2013). Pada waktu yang berbeda, pernah terjadi pula perkelahian antara mahasiswa Sumba dan mahasiswa Alor (Hasanudin, 2012), dan tawuran antar mahasiswa NTT di Tambak Bayan yang menimbulkan kerusakan pada tempat usaha warga (Detik, 2007).

Kejadian - kejadian di atas mempengaruhi komunikasi yang terjadi antara warga Yogyakarta dan mahasiswa NTT yang akan menempuh studi di kota ini, salah satunya karena adanya stereotipe negatif yang dilekatkan kepada mahasiswa NTT. Pada penelitian ini, penulis ingin melihat salah satu aspek mendasar dari komunikasi antar budaya, yakni hambatan komunikasi. Pembahasan tentang hambatan komunikasi yang dialami oleh mahasiswa NTT dapat menjadi uraian benang kusut dari stereotipe dan konflik- konlik yang terjadi dan melibatkan mahasiswa NTT di tempat perantauannya. Pembahasan mengenai aspek-aspek hambatan komunikasi antarbudaya khususnya mengenai hambatan komunikasi antarbudaya dapat ditinjau dari beberapa penelitian sebelumnya. Pertama, Adi Bagus Nugroho, Puji Lestari, Ida Wiendijarti (2012, h.403-418) dengan judul "Pola komunikasi antarbudaya mahasiswa suku Batak di UPN "Veteran" Yogyakarta dan masyarakat asli Yogyakarta”. Penulis menemukan bahwa terdapat perbedaan pola budaya yang dimiliki mahasiswa suku Batak di UPN "Veteran" Yogyakarta dan masyarakat asli Yogyakarta. Pola budaya yang dimiliki oleh mahasiswa suku Batak di UPN "Veteran" Yogyakarta adalah budaya Low Context dan budaya maskulinitas. Sedangkan pola budaya yang dimiliki oleh masyarakat asli Yogyakarta adalah budaya High Context dan budaya Feminitas.

Kedua, penelitian dari Femmita Adelina, Fattah Hanurawan, dan Indah Yasminum Suhanti (2017, h. 1-8) yang berjudul "Hubungan Antara Prasangka Sosial dan Intensi Melakukan Diskriminasi Mahasiswa Etnis Jawa Terhadap Mahasiswa yang berasal dari Nusa Tenggara Timur". Penelitian ini menekankan bahwa prasangka sosial 
mahasiswa etnis Jawa terhadap mahasiswa yang berasal dari Nusa Tenggara Timur sebagian besar termasuk dalam kategori sedang. Sedangkan intensi melakukan diskriminasi mahasiswa etnis Jawa terhadap mahasiswa yang berasal dari Nusa Tenggara Timur sebagian besar juga termasuk dalam kategori sedang. Hasil penelitian ini menunjukkan bahwa ada hubungan positif dan signifikan antara prasangka sosial dan intensi melakukan diskriminasi mahasiswa etnis Jawa terhadap mahasiswa yang berasal dari Nusa Tenggara Timur.

Penelitian lain yang menjadi acuan adalah penelitian yang dilakukan oleh Wihelmina Rosa Laka pada tahun 2015 Penelitian ini berjudul "Studi Deskriptif Perilaku Agresi Mahasiswa Etnis NTT di Yogyakarta". Penelitian ini melihat permasalahan ini dari sisi pandang ilmu psikologi.Berdasarkan hasil penelitianya disimpulkan bahwa perilaku mahasiswa NTT disebabkan oleh tiga faktor.Pertama faktor sosial seperti lingkungan tempat tinggal,rasa solidaritas dan kelompok pertemanan. Kedua, faktor individu mencakup emosi negatif. Ketiga faktor situasional yaitu alkohol.Kekurangan dari penelitian ini adalah penelitian ini hanya melihat faktor kekerasan berdasarkan satu sudut pandang saja. Hal ini tentu saja menyebabkan penelitian ini kurang luas terjait pembahasanya.

Penelitian ini mengungkapkan bagaimana hambatan komunikasi yang terjadi diantara mahasiswa-mahasiswi NTT di Yogyakarta. Tujuan peneltian ini adalah untuk mengetahui hambatan komunikasi antarbudaya mahasiswamahasiswi NTT di Yogyakarta.Selain itu penelitian ini bertujuan untuk mengidentifikasi masalah-masalah yang diakibatkan oleh hambatan-hambatan komunikasi antarbudaya mahasiswamahasiswi NTT di Yogyakarta. Manfaat penelitian ini adalah : (1) Penelitian ini bermanfaat untuk mengimplementasikan teori hambatan komunikasi,teori interprtasi simbolik dan persepsi budaya.,(2). Penelitian ini diharapkan dapat memberikan pengetahuan dari segi akademis khususnya komunikasi antarbudaya.

Manfaat lain dari penelitian ini adalah: (1). Untuk mengetahui proses hambatan komunikasi antarbudaya yang terjalin antara mahasiswa etnis NTT di Yogyakarta.,(2). Penelitian ini di harapkan dapat memberikan pandangan yang baru mengenai hambatan komunikasi yang terjalin selama ini diantara mahasiswamahasiswi NTT.(3).Mengurangi terjadinya potensi konflik yang mungkin 
saja bisa terjadi diantara mahasiswa NTT di Yogyakarta.

\section{TINJAUAN PUSTAKA}

\section{Persepsi Budaya dan Hambatan}

\section{Komunikasi Antar Budaya}

Mulyana (2008, h.18) mengemukakan bahwa persepsi merupakan inti komunikasi karena jika persepsi kita tidak akurat, tidak mungkin kita berkomunikasi dengan efektif. Persepsi yang menentukan apakah seseorang akan memilih suatu pesan untuk diproses atau mengabaikan pesan tersebut. Hal ini yang menyebabkan semakin tinggi derajat kesamaan persepsi antar individu, semakin mudah dan semakin sering mereka berkomunikasi. Konsekuensinya dari proses persepsi ini adalah semakin menguatnya identitas kelompok budaya tertentu.

Persepsi menjelaskan bahwa setiap simbol yang diberikan kepada orang lain belum tentu dipersepsi sama dengan apa yang akan diharapkan oleh pengirim pesan harapkan. Proses interpretasi dan pengalaman yang terjadi pada seseorang dapat memungkinkan seseorang tersebut memiliki persepsi yang sama terhadap informasi yang akan disampaikan. Hal ini tentu saja disebabkan oleh proses belajar dan perbedaan pengalaman yang terjadi pada masa lalu orang tersebut.
Sereno dan Bodaken (dalam Mulyana,2008, h. 181) menyebutkan bahwa persepsi terdiri dari tiga aktivitas, yaitu : seleksi, organisasi, dan interpretasi. Seleksi mencakup sensasi dan atensi, sedangkan organisasi melekat pada interpretasi, yang dapat didefinisikan sebagai peletakan suatu rangsangan bersama rangsangan lainnya.

Pada proses persepsi, tidak jarang muncul prasangka. Prasangka sendiri menurut Gordon Allport (dalam Liliweri, 2005, h.199) merupakan pernyataan atau kesimpulan tentang sesuatu berdasarkan perasaan atau pengalaman yang dangkal terhadap seseorang atau sekelompok orang tertentu. Prasangka juga diartikan sebagai suatu kekeliruan persepsi terhadap orang yang berbeda adalah prasangka. Prasangka adalah sikap yang tidak adil terhadap seseorang atau suatu kelompok.

Ada keterkaitan antara persepsi budaya dan diskriminasi. Persepsi budaya yang keliru terhadap suatu masyarakat atau etnis tertentu dapat menentukan sikap seseorang. Jika persepsi tersebut negatif tentu saja dapat menyebabkan diskiriminasi terhadap suatu kelompok tertentu.

Diskriminasi adalah perilaku negatif yang ditujukan kepada orang lain. Diskriminasi, menurut Samovar, dkk 
(2017, h. 394) adalah sebuah upaya "mengecualikan" atau "mengekslusi" seseorang atau kelompok dari berbagai akses peluang, layanan, maupun kehidupan sosial lain. Tindakan ini merupakan salah satu bentuk manifestasi dari prasangka.

Diskriminasi dapat beraneka ragam bentuknya, seperti perilaku mengabaikan, menggunakan bahasa yang tidak dipahami kelompok tertentu saat berkomunikasi, berbuat kasar, berbuat tidak adil, menjelek-jelekkan, mengancam, dan menyakiti. Jika prasangka sosial merupakan komponen afektif dari antagonisme etnis, maka diskriminasi merupakan komponen behavioral dari antagonisme etnis. Dari konsep intensi dan diskriminasi di atas, peneliti menyimpulkan bahwa intensi melakukan diskriminasi adalah probabilitas seseorang untuk melakukan perilaku negatif terhadap individu atau kelompok lain.

Komunikasi antarbudaya adalah komunikasi antara orang-orang yang berbeda kebudayaan, misalnya antar suku bangsa, antar etnik dan ras, antar kelas sosial. Pada konteks globalisasi, komunikasi antarbudaya memerlukan adanya saling pengertian antara satu budaya dengan budaya lain (Samovar, Porter, McDaniel, Roy, 2015, h. 16). Pada proses komunikasi antarbudaya, menurut Fajar (2009, h. 298-299) Ada sejumlah faktor yang menyebabkan pentingnya komunikasi antarbudaya. Faktor-faktor tersebut antara lain :

\section{Mobilitas}

Mobilitas dalam komunikasi antarbudaya berarti perpindahan individu dari suatu lingkungan budaya yang lama menuju suatu lingkungan yang baru. Hal ini menyebabkan adanya masyarakat baru pada suatu lingkungan yang baru. Pada lingkungan yang baru tersebut, individu tentu saja membutuhkan komunikasi antarbudaya untuk beradaptasi terhadap suatu lingkungan yang ada.

\section{Saling Ketergantungan ekonomi}

Ekonomi menyebabkan seseorang untuk berusaha untuk berinteraksi dengan orang lain. Interaksi ini kemudian menyebabkan seseorang harus mulai mengenal budaya orang lain. Hal ini menjadikan ekonomi sebagai faktor penting dalam komunikasi antarbudaya.

\section{Teknologi Komunikasi}

Teknologi komunikasi yang ada tentu saja menjadi sangat penting dalam komunikasi antarbudaya. Komunikasi antar budaya meningkatkan arus teknologi informasi dan komunikasi yang ada. Perekmbangan teknologi komunikasi dan informasi menyebabkan suatu lingkungan 
masyarakat yang ada berusaha untuk mempelajari komunikasi antarbudaya

1) Komunikasi Antarbudaya terdapat hambatan komunikasi. Menurut Suprapto (Suprapto,2009: 14), hambatan dari proses komunikasi yaitu :

2) Hambatan dari pengirim pesan, misalnya pesan yang disampaikan oleh pengirim belum jelas,perasaan atau situasi emosional yang dialami oleh pengirim pesan sangat mempengaruhi pesan yang akan disampaikan. Hal ini tentu saja mempengaruhi motivasi yang akan mendorong seseorang untuk bertindak sesuai dengan keinginan dan kebutuhan yang dimilikinya

3) Hambatan dalam penyandian/simbol.

Hal ini terjadi dikarenakan proses penggunaan bahasa yang digunakan mengalami bias makna,dimana antara pengirim dan penerima tidak mengalami kesamaan makna

4) Hambatan Media, Hambatan yang terjadi dalam penggunaan media komunikasi,misalnya gangguan pada pemancar televisi sehingga berpengaruh dalam menerima informasi yang disampaikan didalam media televisi tersebut

5) Hambatan dalam bahasa sandi. Hambatan dalam menafsirkan sandi oleh penerima pesan dari pemberi pesan
6) Hambatan dari penerima pesan. Kurangnya perhatian dalam menerima ataupun mendengarkan pesan. Hal ini dipengaruhi oleh sikap yang keliru atau juga bias informasi.

DeVito (2018) mengemukakan pula bahwa hambatan dalam Komunikasi Antar Budaya mencakup hal-hal berikut

1) Pengabaian perbedaan antar kelompok yang berbeda budaya. Hambatan ini merupakan hambatan yang sering terjadi terutama jika dikaitkan dengan persoalan nilai, sikap dan kepercayaan.

2) Pemberian stereotipe karena terjebak pada pengabaian adanya budaya yang berbeda.

3) Mengabaikan perbedaan dalam makna.

4) Melanggar adat kebiasaan kultural, yaitu peraturan komunikasi yang ada berdasarkan kultur-kultur sendiri. Aturan ini menetapkan mana yang patut dan mana yang layak dan tidak layak untuk dilakukan

5) Menilai perbedaan secara negatif, maksudnya adalah sekalipun telah dipahami adanya perbedaan diantara kultur-kultur,perbedaan ini tidak boleh dianggap sebagai sesuatu hal yang negatif. Pada hambatan komunikasi antarbudaya, salah satu hal yang 
berpengaruh adalah sikap etnosentrime. Menurut Zastrow (dalam Liliweri, 2002, h.168) Etnosentrisme merupakan suatu kecenderungan untuk memandang normanorma dan nilai dalam kelompok budayanya sebagai yang absolute dan digunakan sebagai standar untuk mengukur dan bertindak terhadap semua kebudayaan yang lain. Etnosentrisme memunculkan sikap prasangka dan streotip negatif terhadap etnik atau kelompok lain. Etnosentrime memiliki tiga tingkatan didalam masyarakat menurut Samovar,dkk (2017) yaitu:

1) Positif, merupakan kepercayaan bahwa budaya yang kita miliki merupakan budaya yang lebih baik dari budaya yang lain. Budaya ini merupakan hal yang bersifat alami dan kepercayaan yang kita anut berasal dari budaya asli yang kita miliki.

2) Negatif, kita mengevaluasi budaya yang ada disekeliling kita secara sebagian. Kita percaya bahwa budaya yang kita miliki adalah pusat dari segalanya atau budaya yang miliki adalah inti dari semua budaya yang lain. Budaya lain tersebut harus diukur berdasarkan standar budaya yang kita miliki

3) Sangat negatif, kita tidak cukup menganggap budaya kita sebagai budaya yang paling benar dan bermanfaat, kita menganggap bahwa budaya yang kita miliki paling berkuasa dibandingkan budaya yang lain. Kita percaya bahwa nilai dan kepercayaan kita harus diadopsi oleh orang lain.

\section{METODE PENELITIAN}

Penelitian ini menggunakan metode peneltian kualitatif dengan metode pengumpulan data yaitu wawancara dan studi pustaka. Subjek penelitian ini adalah 4 orang mahasiswa yang berasal dari NTT,yang berkuliah di beberapa perguruan tinggi di Yogyakarta. Para informan dalam penelitian ini adalah:

1) MG: mahasiswa NTT yang juga pernah menjabat sebagai Ketua Komunitas Mahasiswa NTT Yogyakarta Periode 2018-2019

2) DF: mahasiswa Ilmu Komunikasi universitas swasta di Yogyakarta angkatan 2014

3) EB: mahasiswa S2 di salah satu universitas negeri di Yogyakarta

4) RH mahasiswa universitas swasta di Yogyakarta.

Setelah pengumpulan data dengan wawancara, hasilnya akan melalui tahap berikut: (1). Reduksi Data. Reduksi data merupakan proses untuk memisahkan data yang perlu dan tidak perlu dari data yang ditemukan didalam penelitian,sehingga data-data yang ditemukan tersebut menjadi 
lebih fokus terhadap tujuan penelitian yang akan dilakukan. Data-data mengenai pandangan, opini, serta cerita mengenai interaksi sosial khususnya mengenai hambatan komunikasi yang dialami oleh mahasiswa NTT di Yogyakarta dari para informan yang telah terkumpul setelah wawancara dan observasi berlansung. (2) Penyajian Data. Penyajian data merupakan langkah-langkah yang dilakukan dengan membuat perencanaan dan mendeskripsikan secara tekstual hasil wawancara dan observasi yang diambil secara kualitatif. Data dari para informan ini masih merupakan data rekaman suara. Pada proses wawancara, penulis juga melakukan wawancara dengan sesepuh dan penggiat komunitas NTT yang sudah sejak lama tinggal di Yogyakarta sebagai data pendukung.

Tahap studi pustaka merupakan tahap pengumpulan data pendukung untuk mendeskripsikan dinamika sosial budaya dari mahasiswa NTT di Yogyakarta melalui literatur dan pemberitaan di media. Setelah melakukan studi pustaka dan menganalisis hasil penelitian, penulis melakukan penarikan kesimpulan. Hal ini dilakukan setelah memaparkan data hasil observasi dan wawancara hambatan Komunikasi antarbudaya mahasiswa NTT di Yogyakarta.
HASIL PENELITIAN DAN

PEMBAHASAN

Kedatangan Mahasiswa Nusa Tenggara Timur di Yogyakarta

Berdasarkan penuturan sesepuh dan data litetarur, kedatangan mahasiswa NTT di Yogjakarta dapat dibagi kedalam tiga periode waktu yakni generasi pelajar tahun 1940-1950, generasi mahasiswa kedua periode 1980-2000 dan generasi mahasiswa ketiga periode awal tahun 2000an hingga sekarang. Pada tahun 1983 atas prakarsa salah satu sesepuh di Yogyakarta yaitu Pak John Keban dibentuklah dua organisasi mahasiswa yaitu Flobamora dan IMF (Ikatan Mahasiswa Flobamorata). Organisasi Flobamora bertujuan untuk menghimpun mahasiswa NTT di Jogja bagian utara. Pada tahun 1990 kedua paguyuban ini disatukan menjadi satu organisasi yaitu Flobamora.

Organisasi Flobamora memiliki beberapa tujuan antara lain: menghimpun dan merangkul mahasiswa NTT di Yogyakarta. Organisasi flobamora bertanggung jawab memberi pengarahan bagi mahasiswa baru sebelum berbaur dengan masyarakat dan memberikan bekal sebelum perkuliahan di kampus-kampus.

Pada tahun 2000-sekarang arus kedatangan mahasiswa NTT ke 
Yogyakarta sangat tinggi. Tingginya minat ini dipengaruhi oleh beberapa hal yaitu mutu pendidikan yang baik, biaya hidup murah, kenyamanan kota dan lingkungan, ikut teman dan keluarga.Mahasiswa NTT pada periode ini mulai membentuk dan berpencar ke masing-masing organisasi kedaerahan. Beberapa organisasi mahasiswa diantaranya adalah PERKURAY (Persatuan Kupang Raya), IKAMAYA (Ikatan Mahasiswa Manggarai Yogyakarta), HIPMASTY (Himpunan Mahasiswa Sumba Timur), KBNY (Keluarga Besar Ngada Yogyakarta),IMAY (Ikatan Mahasiswa Adonara Yogyakarta). Dari sekian organisasi kedaerahan mahasiswa NTT di Yogyakarta terdapat beberapa yang aktif memprmosikan budaya,misalnya KMKS (Keluarga Mahasiswa Katolik Sumba Yogyakarta) yang mementaskan budaya dan tari tradisional. Selain itu ada "Wangak", kelompok musik tradisional yang berasal dari Maumere yang sering menampilkan music-musik tradisional pada acara-acara kebudayaan. Adapun organisasi yang mengembangkan minat akademis, seperti komunitas KESA yang bergerak pada dikskusi mengenai desa dan politik.

Pada periode 2000-sekarang mulai muncul benih-benih konflik mahasiswa
NTT dengan masyarakat Yogyakarta, khususnya wilayah Tambak bayan dan Babarsari yang banyak dihuni oleh mahasiswa-mahasiswa yang berasal dari NTT. Konflik-konflik ini menyebabkan reaksi penolakan warga Tambak Bayan dan warga Yogyakarta secara umumnya untuk tidak menerima mahasiswa NTT menempati kos dan rumah kontrakan di wilayah mereka. Penolakan ini nampak dalam aturan dan kriteria-kriteria khusus bagi calon penghuni kos atau rumah kontrakan seperti tidak menerima mahasiswa-mahasiswi NTT di kos atau rumah kontrakan mereka.

Pendatang dari NTT yang menetap di Yogyakarta mencari teman sesama etnis kemudian membentuk paguyuban kedaerahan. Salah satu contohnya adalah Paguyuban Keluarga Manggarai Yogyakarta. Paguyuban ini sebagai wadah bagi kelurga etnis Flores Manggarai Yogyakarta untuk berkumpul bersama. Etnis Paguyuban Manggarai mempunyai kegiatan budaya tahunan di Yogyakarta yakni tarian caci di halaman Pakualaman. Kegiatan ini sudah menjadi agenda rutin tahunan. Acara ini juga dihadiri oleh etnisetnis Manggarai Yogyakarta seperti Semarang, Solo dan Surabaya.

Pola pemukiman orang NTT di Yogyakarta pada umumnya tersebar di 
wilayah-wilayah sekitaran Yogyakarta. Rata-rata orang NTT tidak memilki kesepakatan yang sama mengenai tempat dimana mereka ankan tinggal. Tempat tinggal mahasiswa-mahasiswi NTT biasanya berbaur dengan masyarakat Yogyakarta. Berdasarkan diskusi dengan beberapa informan yang telah dilakukan oleh peneliti, terdapat beberapa pertimbangan dalam memilih lokasi tempat tinggal yaitu kenyamanan lingkungan dan berdekatan dengan lokasi pendidikan.

Kehadiran mahasiswa NTT di Yogyakarta membawa warna dan dinamika budaya tersendiri. Gejala konflik mahasiswa NTT mulai muncul pada tahun 2000an, pada masa ini banyak mahasiswa yang berpencar dan tidak aktif berorganisasi di perkumpulan mahasiswa NTT. Pada masa ini, banyak mahasiswa dari beragam etnik di NTT memisahkan diri dari organisasi induk Flobamora. Hal ini menyebabkan pola hunian berbasis etnis dan kesukuan mulai marak di Yogyakarta. Akibatnya, mahasiswa NTT tidak mengalami banyak interaksi dengan warga dari daerah lain di sekitarnya. Hal ini jelas membawa dampak pada dinamika komunikasi antar budaya yang dialami oleh para mahasiswa.
Selain itu, terjadinya beberapa kasus yang melibatkan mahasiswa NTT di Yogyakarta menjadi pemicu terjadinya keterbatasan dinamika antar budaya. Hal ini juga memperuncing hambatanhambatan komunikasinya. Kasus-kasus tersebut antara lain:

\section{1) Kasus Penembakan di Lapas}

\section{Cebongan}

Penembakan di Lapas Cebongan pada tahun 2013 membawa dampak signifikan bagi mahasiswa NTT. Dampak nyata pasca peristiwa penyerangan Cebongan ternyata memberikan efek yang besar khususnya dalam hubungan antar mahasiswa NTT dengan warga Yogyakarta. Setelah terjadi penembakan di lapas Cebongan, terjadi penolakan kepada mahasiswa NTT yang sedang mencari kos di Yogyakarta. Selain penolakan, juga terjadi teror melalui SMS. Teror ini memberikan rasa tidak aman kepada mahasiswa NTT karena ada ancaman berupa SMS yang beredar bahwa akan diadakan sweeping / pembersihan mahasiswa NTT di Yogyakarta. Hal ini tentu saja memberikan rasa tidak nyaman terhadap mahasiswa NTT khususnya untuk beraktivitas, seperti berangkat ke kampus untuk kuliah (Okezone, 2013).

2) Perkelahian antar Mahasiswa NTT di Tambak Bayan 
Perkelahian antar mahasiswa NTT di Tambak Bayan, Babarsari, Yogyakarta melibatkan mahasiswa dari Kupang dan Timor Leste (Detik, 2007). Perkelahian ini disebakan konsumsi miras yang kemudian memicu konflik diantara kedua kubu mahasiswa tersebut. Mahasiswa Timortimur yang sedang dalam keadaan mabuk melakukan kekerasan fisik terhadap mahasiswa Kupang. Hal ini kemudian menyebabkan penyerangan terhadap koskosan mahasiswa Timor-timur oleh mahasiswa Kupang. Akibat dari perkelahian ini menyebabkan beberapa warung milik warga Tambak Bayan tutup dan hal ini tentu saja menggangu ketengan warga.

\section{3) Perkelahian antara Mahasiswa}

\section{Sumba dan Mahasiswa Alor}

Bentrokan ini dipicu oleh masalah sepele, hal ini disebabkan oleh saling ejek diantara kedua kelompok. Saling ejek ini kemudian memicu konflik yang lebih besar. Bentrokan ini mengakibatkan adanya perusakan rumah kos-kosanterutama kos yang dihuni oleh kedua kelompok tersebut. Peristiwa ini tidak menyebabkan korban jiwa, namun membuat wilayah Tambak Bayan sempat mencekam. Kedua kelompok ini kemudian sepakat berdamai setelah diamankan oleh pihak kepolisian (Hasanudin, 2012).
Hambatan Komunikasi Antar Budaya Mahasiswa NTT di Yogyakarta

Suatu kebudayaan memberikan pengalaman bagaimana proses informasi dikelola berdasarkan suatu interaksi yang terjadi pada lingkungan masyarakat.Setiap daerah tentu mempunyai budaya yang beragam sehingga tentu saja dapat mempengaruhi komunikasi yang terjadi pada individu atau kelompok tersebut. Hal ini kemudian dapat mempengaruhi proses komunikasi khususnya dapat memunculkan hambatan komunikasi. Hambatan komunikasi bisa menjadi bagian yang penting dalam proses interaksi yang terjadi di masyarakat.

Hal pertama yang menjadi hambatan dalam komunikasi antar budaya mahasiswa NTT di Yogyakarta adalah masalah bahasa. Salah satu informan yang mangalami ini adalah DF. DF menuturkan bahwa ia mengalami kesulitan saat beinteraksi dengan masyarakat lain yang bukan berasal dari NTT. Pada masa awal DF berada di Yogyakarta, ia mengemukakan bahwa ia berusaha menyesuaikan diri dengan lingkungan baru. Proses penyesuaian ini ia lakukan dengan lebih banyak berinteraksi dengan teman sesama dari NTT. 
"Kalau dulu awal masuk kuliah saya lebih nyaman berkomunikasi dengan orang orang yang berasal dari NTT karena pada saat awal kuliah saya masih berusaha untuk menyesuaikan dengan orang baru, budaya baru serta lingkungan baru.Jadi butuh orang yang sesama dari NTT sebagai teman untuk menghadapi sesuatu yang baru di Yogykarta, hal ini dilakukan untuk berinteraksi dengan warga Yogyakarta. Saya juga banyak mengikuti kegiatan yang diikuti oleh banyak mahasiswa NTT dan juga dari luar NTT" (DF wawancara tanggal 4 November 2019)

Pada proses penyesuaian ini, DF melihat bahwa perbedaan dialek dan bahasa menjadi alasan DF mengalami kesulitan saat berinteraksi dengan warga sekitar kosnya.

"Ada beberapa kalimat atau kata yang memiliki arti berbeda misalnya kata sorong bagi kami orang NTT artinya berpindah tempat, tapi memiliki arti yang berbeda bagi orang jawa. Hal tersebut mempengaruhi dina saat berkomunikasi karena takutnya nanti apa yang dikatakan dina bisa ditafsirkan berbeda. Terus, Awal-awal saya masih kaku untuk berkomunikasi. Komunikasi saya agak susah karena mayoritas orang asli Yogyakarta masih mencampur bahasa Indoensia dan bahasa Jawa dalam proses komunikasi disekitar lingkungan saya, malah terkadang lebih banyak bahasa Jawa dibandingkan bahasa Indonesia (DF, wawancara tanggal 14 November 2019).
Pencampuran antara bahasa Indonesia dengan bahasa Jawa disebutkan DF sebagai hambatan baginya selama menyesuaikan diri dengan lingkungannya. Hal ini dikarenakan keterbatasannya memahami bahasa Jawa itu sendiri. Hal inilah yang menyebabkan DF lebih nyaman berkomunikasi dengan teman sesama dari NTT karena adanya persamaan bahasa. Selain DF, informan lain yang juga mengalami hambatan adalah RH. Pengalaman RH saat berkuliah mengemukakan bahwa ia menggunakan bahasa yang berbeda dengan orang yang bukan berasal dari NTT.

Hambatan komunikasi antar budaya tidak berhenti pada persoalan bahasa saja. Salah satu hal yang berpengaruh adalah sikap etnosentrime. Menurut Zastrow (dalam Liliweri, 2002) Etonesntrime adalah kecendrungan seorang individu untuk melihat suatu norma dan nilai dalam kelompoknya sebagai sesuatu yang mutlak. Hal ini kemudian digunakan sebagai standar untuk mengukur kebudayaan yang lain. Etnosentrisme memunculkan sikap prasangka dan streotip negatif terhadap etnik atau kelompok lain. Etnosentrisme dimunculkan oleh kelompok masyarakat non NTT maupun dilakukan oleh mahasiswa NTT itu sendiri. Etnosentrisme 
yang dimunculkan oleh masyarakat non NTT, dalam hal ini masyarakat di sekitar tempat kos mahasiswa NTT di Yogyakarta adalah anggapan bahwa Jawa jauh lebih maju daripada NTT. Padangan bahwa NTT terbelakang dan primitif muncul melalui pengalaman informan DF yang sering ditanyai mengenai ketersediaan listrik dan makanan.

Hambatan lain juga ada pada mahasiswa NTT sendiri yang melakukan sikap etnosentrime dari mahasiswa NTT sendiri. Etonesntrisme adalah sikap yang menganggap budaya kita sebagai budaya yang paling benar dibandingkan budaya lainnya, kita menganggap budaya yang kita miliki paling berkuasa dibandingkan budaya yang lain. Kita percaya bahwa nilai dan kepercayaan kita harus diakui oleh orang lain. Hal ini muncul pada informan EB yang mengatakan bahwa kebudayaan NTT adalah yang paling superior sehingga EB memiliki sudut pandang bahwa kebudayaan lain di luar NTT dipandang rendah dibandingkan dengan budaya yang EB miliki. EB saat awal kuliah merasa seenaknya seperti contoh membunyikan suara musik dengan keras karena menurutnya, di NTT hal tersebut sudah sangat lumrah.

DeVito (2018) mengemukakan pula bahwa hambatan dalam Komunikasi Antar
Budaya. Pada hasil wawancara dengan para informan, maka dapat dilihat bahwa hambatan komunikasi antar budaya yang dialami mencakup hal-hal berikut:

- Mengabaikan perbedaan antara anda dan kelompok yang secara kultural berbeda. Pengabaian ini merujuk pada sikap pelaku komunikasi yang menyamakan budayanya dengan budaya orang lain. Hal ini, ditunjukkan pada sikap EB yang menyalakan musik keras-keras di kosnya karena merasa bahwa hal itu lumrah dilakukan di daerah asalnya. Tindakan EB ini mengabaikan bahwa tempat kosnya yang berada di Yogyakarta memiliki budaya berbeda dengan NTT.

- Terjebak dalam stereotipe: Stereotipe atau pelabelan merupakan hambatan dalam komunikasi antar budaya karena stereotipe ini mengganggu cara pandang yang seharusnya objektif. Stereotipe muncul karena adanya kejadian, penanaman mitos yang kuat maupun yang berasal dari prasangka. Pada penelitian ini, dapat dilihat bahwa stereotipe dialami oleh para mahasiswa NTT melalui anggapan bahwa NTT merupakan daerah yang terbelakang, memiliki keterbatasan akses teknologi dan pembangunan. Selain itu, stereotipe bahwa mahasiswa NTT merupakan sumber masalah dan pemicu konflik menjadi hambatan bagi mahasiswa 
NTT untuk hidup membaur dengan masyarakat lain di Yogyakarta.

\section{Stereotipe dan Diskriminasi pada Mahasiswa NTT}

Stereotipe adalah pandangan umum masyarakat erat kaitanya dengan prasangka. Stereotip merupakan suatu penilaian secara umum oleh suatu kelompok kepada kelompok masyarakat lain. Menurut Liliweri (2005, h.199) prasangka adalah suatu hambatan didalam kegiatan komunikasi. Dalam prasangka, emosi memaksa kita untuk kesimpulan tang menggunakan suatu fakta yang ada.Oleh sebab itu,prasangka akan membuat seseorang akan berpikir tidak objektif dan segala sesuatu yang dilihatnya akan dinilai secara negatif.

Prasangka bermula dari persepsi yang merupakan inti komunikasi. Menurut Mulyana (2008, h.18), persepsi dikatakan sebagai inti komunikasi karena jika persepsi kita tidak akurat, tidak mungkin kita berkomunikasi dengan efektif. Persepsi yang menentukan kita memilih suatu pesan dan mengabaikan pesan yang lain. Semakin tinggi derajat kesamaan persepsi antar individu, semakin mudah dan semaskin sering mereka berkomunikasi, dan sebagai konsekuensinya semakin cenderung membentuk kelompok budaya atau kelompok identitas.

Persepsi menjelaskan bahwa setiap simbol yang kita kirimkan kepada orang lain belum tentu sama dengan apa yang akan kita harapkan. Proses interpretasi dan pengalaman yang terjadi pada seseorang dapat memungkinkan seseorang tersebut memiliki persepsi yang sama terhadap informasi yang akan kita sampaikan. Hal ini tentu saja disebabkan oleh proses belajar dan perbedaan pengalaman yang terjadi pada masa lalu orang tersebut.

Gordon Allport dalam Liliweri (2005, h.199) mengemukakan bahwa prasangka merupakan pernyataan atau kesimpulan tentang sesuatu berdasarkan perasaan atau pengalaman yang dangkal terhadap seseorang atau sekelompok orang tertentu. Prasangka juga diartikan sebagai suatu kekeliruan persepsi terhadap orang yang berbeda adalah prasangka. Prasangka adalah sikap yang tidak adil terhadap seseorang atau suatu kelompok.

Diskriminasi, menurut Samovar, dkk (2017, h. 394) adalah sebuah upaya "mengecualikan" atau "mengekslusi" seseorang atau kelompok dari berbagai akses peluang, layanan, maupun kehidupan sosial lain. Tindakan ini merupakan salah satu bentuk manifestasi dari prasangka. 
Perilaku diskriminasi bersumber dari sikap seseorang yang didahului dengan rasa prasangka. Ada keterkaitan antara persepsi budaya dan diskriminasi. Persepsi budaya yang keliru terhadap suatu masyarakat atau etnis tertentu dapat menentukan sikap kita. Jika persepsi tersebut negatif tentu saja dapat menyebabkan diskiriminasi terhadap suatu kelompok tertentu. Sarwono dan Eko (2009) menjelaskan diskriminasi sebagai perilaku negatif terhadap orang lain yang menjadi target prasangka. Diskriminasi merupakan tingkah laku di mana individu atau kelompok memperlakukan orang secara berbeda karena keanggotaan orang itu. Diskriminasi yang dialami oleh kelompok budaya tertentu dapat memicu adanya hambatan komunikasi antar budaya pada proses interaksi dan dinamika masyarakat. Stereotipe kemudian menimbulkan prasangka. Stereotipe seperti ini juga dialami oleh mahasiswa NTT.

"Pernah mengalami tapi lebih mengarah kearah makanan atau geografis. Kalau pengalaman yang saya dapat itu pernah satu kali ikut doa dilingkungan terus setelah doa, dilanjutkan dengan snack, nah pada saat itu tuan rumah memberikan snack singkong goreng kemudian salah satu orangtua langsung kaya bilang ini ih singkong. Pasti disana makanannya ubi terus kan, jadi seolah-olah orang timur itu atau NTT makanan sehari-harinya itu ubi. Kemudian stereotype yang kedua mereka itu lebih ke wilayah geografis. Pengalaman saya saat bekerja di warnet itu ada teman yang bertanya di NTT itu ada listrik enggak, terus saya bilang adalah. Kemudian dia bertanya lagi, NTT itu ada pelabuhan nggak. Jadi seolah-olah mereka berpikir kalau NTT itu sangat terbelakang dan kurang pembangunan, jadi yang ada dipikiran mereka, NTT itu cuman ada hutan" (DF wawancara tanggal 14 November 2019)

Hal ini menunjukkan adanya stereotipe terhadap mahasiswa NTT yang masih dianggap terbelakang. Berkaitan dengan stereotipe, hal yang sama juga disampaikan oleh EB. EB sering mendapat perlakuan yang kurang menyenangkan. Menurut EB, NTT sering dipandang sebagai tempat yang asing dan terpencil. Hal ini kemudian diperkuat dengan persepsi negatif yang pernah dialami oleh EB. Ia menuturkan bahwa sering tidak mendapatkan kos-kosan atau rumah kontrakan karena asal dia yang dari NTT.

"Saya pernah mengalami kesulitan saat mencari kos atau rumah kontrakan. Apalagi ketika meraka tahu saya berasal dari NTT, beberapa kali penolakan pernah saya rasakan. Bahkan adakalanya saat mencari kos atau rumah kontrakan, saya kadangkadang mengaku bukan berasal dari NTT tujuannya kemungkinan saya ditolak cukup kecil. Bahkan sering 
kali ada yang mengecek KTP saya, untuk memastikan hal itu "(EB, wawancara 16 November 2019)

Kesulitan mendapatkan kos yang dialami oleh mahasiswa dari NTT ini membuat pemilik kos memberikan peringatan awal kepada mahasiswa NTT jika ingin tinggal di rumah kosnya. Tidak jarang, pemilik kos menolak mahasiswa NTT karena menurut mereka anak NTT sering membuat masalah.

"pernah, pada saat saya awal masuk kos-kosan, bapak kos-kosan langsung mengatakan 'Mas jangan buat rusuh yah", padahal saya baru beberapa jam tinggal distu, setelah itu pemilik kos tersebut mengatakan "Soalnya anak NTT sering buat ribut,". Sudah ada persepsi kepada saya bahwa saya akan membuat keributan" (wawancara Eugenius, 16 November 2019)

Mahasiswa NTT sering mendapat stereotipe beradasarkan asal mereka. Mahasiswa NTT sering mendapat stereotipe beradasarkan asal mereka. Terkadang stereotipe yang mereka alami cenderung negatif. Hal ini juga dialami oleh mahasiswa NTT yang sering kesulitan saat mencari kos. Hal ini dikemukakan oleh EB dalam wawancara mengungkapkan bahwa ia sering tidak mendapatkan kos-kosan atau rumah kontarakan karena asal dia yang dari NTT. Selain itu, informan MG juga mengemukakan bahwa teman-temannya sering kesulitan mencari kos-kosan sehingga mereka memutuskan untuk patungan dan membayar rumah kontrakan. Alhasil, pengalaman dan interaksi yang dimiliki oleh mahasiswa NTT ini didominasi oleh teman sesama dari NTT dan kurang berinteraksi dengan warga lokal.

Suatu kebudayaan pasti memiliki dinamika mengenai individu yang berusaha untuk memproses informasi atau suatu pesan. Pesan itu kemudian disebarkan dari individu ke lingkungan sekitarnya. Setiap daerah di Indonesia mempunyai suatu sistem kebudayaan yang berbeda-beda. Perbedaan ini tentunya sangat mempengaruhi dinamika komunikasi antar budaya yang ada di tengah masyarakat. Perbedaan ini kemudian melahirkan hambata-hambatan komunikasi antar budaya yang tentunya bisa mempengaruhi komunikasi yang terjadi ditengah lingkungan masyarakat. Salah satunya melalui penolakan pemilik kos yang tidak mau menerima mahasiswa NTT menjadi penghuni kosnya. Khususnya di wilayah Tambak Bayan, Babarsari, Yogyakarta. Hal ini disebabkan sikap dan tindakan mahasiswa NTT yang sering bentrok dengan warga sekitar maupun dengan sesama mahasiswa NTT. 
Tindakan seperti ini kemudian menyebabkan ada sebagian warga Yogyakaarta yang memiliki pandangan negatif terhadap mahasiswa NTT. Sebagian masyarakat Yogyakarta kemudian merasa terancam dan menolak kehadiran mahasiwa NTT.

Beberapa informan dalam penelitian ini mengatakan tindakan penolakan ini, sebenanya tidak seharusnya terjadi terhadap mahasiswa-mahasiswi NTT. Hal ini seperti yang disampaikan informan $\mathrm{RH}$ dalam wawancara. RH mengatakan, bahwa maraknya pengusiran atau penolakan kos harus segera dicari solusinya. RH menuturkan bahwa perlu adanya pertemuan antara RT/RW setempat dengan teman-teman NTT untuk mengetahui alasan jelas kenapa temanteman NTT mendapatkan perlakuan seperti itu. RH menuturkan :

"Pandangan saya terkait maraknya pengusiran atau penolakan kos atau rumah kontrakan terhadap mahasiswa-mahasiswi yang berasal dari NTT ialah salah satu solusi dari saya sebaiknya diadakan rapat atau musyawarah RT/RW setempat dengan teman-teman NTT untuk mengetahui alasan jelas kenapa teman-teman NTT tidak boleh tinggal (Kos) dan mendapat perlakuan yang kurang baik. Stigma tentang NTT tidak boleh dibawah ke generasi berikutnya karena tidak semua anak NTT itu melakukan tindakan buruk (berkelahi,mabuk dll). Saya juga dulu pernah 3 kali ditolak saat mencari kos. Saat itu ada tertera tulisan "kos puteri masih ada kamar" tapi saat di tanya asalnya dan saya beritahu dari NTT seketika langsung kamarnya penuh. Dan pernah satu kali mencari kos untuk teman cowok di daerah Tambakbayan tapi karena di kasih tau kosnya penuh. Tentunya juga saya sebagai anak NTT harus intropeksi diri karena saya sadar bahwa saya merantau ke daerah lain yang budayanya juga lain sehingga saya sebisa mungkin untuk menjaga sikap dan perilaku agar tidak menimbulkan stigma." (wawancara RH, 17 November 2019)

Hal ini tentu saja menunjukan bahwa persepsi terhadap mahasiswa NTT cenderung dipandang masih rendah. Hal ini mengibaratkan stereotipe terhadap mahasiswa NTT masih dianggap terbelakang.

Mahasiswa NTT juga memiliki streotipe terhadap masyarakat lain khususnya terhadap lingkungan sekitar khususnya orang Jawa. Mahasiswa NTT memberikan stereotipe negatif. Stereotipe negatif adalah Negatif, dimana seorang individu mengevaluasi budaya yang ada disekelilingnya dan percaya bahwa budaya yang dia miliki adalah yang paling baik dan budaya yang ada diluar individu tersebut harus diukur berdasarkan budaya yang individu tersebut miliki. 


\section{SIMPULAN}

Melihat dari hasil dari penelitian dan pembahasan, peneliti menemukan hambatan komunikasi antar budaya NTT di Yogyakarta sebagai berikut:

Hambatan-hambatan komunikasi antar budaya mahasiswa NTT di Yogyakarta disebabkan oleh adanya persepsi negatif terhadap mahasiswamahasiswi NTT. Persepsi yang keliru ini kemudian menjadi penyebab adanya diskriminasi terhadap mahasiswamahasiswi NTT.Hambatan komunikasi antar budaya yang terjadi pada mahasiswa NTT berupa bahasa dan diskriminasi serta adanya streotipe terhadap mahasiswamahasiswi NTT.

Stereotipe yang ada pada mahasiswamahasiswi NTT disebabkan oleh adanya pandangan negatif terhadap mahasiswa NTT. Hal ini ditunjukan dengan adanya prasangka serta diskriminasi terhadap mahasiswa-mahasiswi NTT. Salah satu bentuknya adalah tidak menerima mahasiswa-mahasiswi NTT untuk kos ditempat tersebut. Kemudian ada pandangan bahwa orang NTT suka membuat onar dan strerotipe keliru seperti persoalan geografis serta makanan terhadap orang NTT. Konflik yang melibatkan mahasiswa-mahasiswi NTT menyebabkan semakin buruknya citra mahasiswa-mahasiswi NTT ditengah masyarakat Yogyakarta. Konflik-konflik seperti perkelahian yang melibatkan mahasiswa-mahasiswi NTT di Yogyakarta.

\section{DAFTAR PUSTAKA}

Adelina, F., Hanurwan, F., Suhanti, I. Y. (2017). Hubungan Antara Prasangka Sosial Dan Intensi Melakukan Diskriminasi Mahasiswa Etnis Jawa Terhadap Mahasiswa Yang Berasal Dari Nusa Tenggara Timur. Jurnal Sains Psikologi, Vol.6 Nos.1, (1-8). doi: 10.17997/um023v6i12017p001

Detik.(2007, Juli 2).Mahasiswa asal TimTim dan Kupang Bentrok. $<$ news.detik.com/berita/d800263/mahasiswa-asal-timtim-dankupang-kembali-bentrok>

Devito,

$$
\text { A.(2018). }
$$

Human

Communication: The Basic Course. USA: Pearson.

Fajar, M. (2009). Ilmu Komunikasi Teori dan Praktek. Yogyakarta : Graha Ilmu.

Laka, R. W. (2015). Studi Deskriptif Perilaku Agresi Mahasiswa Etnis Nusa Tenggara Timur (NTT) di Yogyakarta. Skripsi, Universitas Sanata Dharma. 
Liliweri, A. (2002). Makna Budaya dalam Komunikasi Antarbudaya. LKiS Yogyakarta: Yogyakarta. (2005) Prasangka dan Konflik, Komunikasi Lintas Budaya Masyarakat Multikultur. Yogyakarta : LKiS

Mulyana, D. (2008) Ilmu Komunikasi,

Suatu Pengantar. Bandung: Remaja Rosdakarya

Nugroho, A. B, Lestari, P., Wiendijarti, I. (2012).Pola Komunikasi Antar Budaya Batak dan Jawa di Yogyakarta.Jurnal ASPIKOM. Vol. 1 Nos.(5). (403-418). doi: 10.24329/aspikom.v1i5.44

Samovar, L., Porter, R.E., McDaniel, E.R., Roy, C.S. (2015). Intercultural Communication : A Reader (14 edition). Boston: Cengage Learning. $-(2017)$

Communication

Between Cultures ( $9^{\text {th }}$ edition).

Boston: Cengage Learning.

Sarwono, S.W. dan Eko, A. M. (2009).

Psikologi Sosial. Jakarta: Salemba Humanika.

Soeprapto, R. (2002). Interaksi Simbolik, Perspektif Sosiologi Modern. Yogyakarta: Averrpes Press dan Pustaka Pelajar
Hasanudin, U. (2012, November 8). Bentrok Antar Mahasiswa di Tambakbayan Kedua Kelompok Berdamai.<https://www.solopos.com/ bentrok-antar-mahasiswaditambakbayan- kedua- kelompokberdamai- $345887>$.

Viva. (2013, Maret 26). Ada 14.000 Warga NTT di Yogya: Mereka Was-Was. $<$ https://www.viva.co.id/berita/nasion al/400501-ada-14-000-warga-ntt-diyogya-mereka-was-was>

Jawapos.(2018, Maret 9). Predikat Jogja Sebagai Kota Pendidikan Dipertaruhkan.<https://www.jawapos .com/jpg- today/09/03/2018/predikatjogja-sebagai-kota-pendidikan dipertaruhkan/>

Pos Kupang. (2013, Juli 12). Diki dari NTT Bangga Bunuh Anggota TNI. <https://kupang.tribunnews.com/2013 /07/12/diki-dari-ntt-bangga-bunuh-an ggota-tni>

Merdeka. (2013, Maret 24). Asrama Mahasiswa NTT Yogyakarta Dikosongkan. $<$ https://www.merdeka. com/peristiwa/asrama-mahasiswa-nttyogyakarta-dikosongkan.html> 